CHINESE ANTS COLLECTED BY PROF. C. W. HOWARD. ${ }^{1}$

By William Morton Wheeler.

Since the publication of my paper on Chinese ants ${ }^{2}$ Professor C. W. Howard has sent me a small collection made in Canton and the immediate vicinity. The collection comprises two very interesting undescribed species and several others which have not been previously recorded from China.

\title{
Ponerinte.
}

1. Stictoponera menadensis Mayr subsp. bicolor Emery $\lcm{-}$ Two specimens from Leng-oo, near Canton.

2. Diacamma rugosum Guill. subsp. geometricum \$m. var. anceps Emery. $\Varangle-N u m e r o u s ~ s p e c i m e n s$ from Canton.

3. Odontoponera transversa Sm. $\Varangle-$ Several specimens from Canton and Honan Island, on which Canton College is situated.

4. Ectomomyrmex astutus $\mathrm{Sm}$. $\Varangle-\mathbf{A}$ single specimen from Leng-oo.

5. Leptogenys (Lobopelta) diminuta Sm. $\Varangle-F i v e$ specimens from Leng-oo.

\section{Pseudom.yrmin ж.}

6. Tetraponera allaborans Walk. \&-A single deälated specimen from Honan Island.

\section{MYRMICINA.}

\%. Monomorium pharaonis L. $\Varangle q-$ Many specimens from Canton.

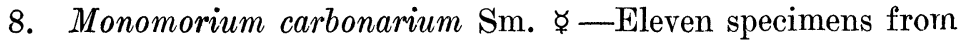
Canton.

9. Cardiocondyla nuda Mayr. $\Varangle-T h r e e$ specimens from Canton.

10. Crematogaster rogenhoferi Mayr. $\Varangle \propto-$ Several specimens from Canton.

11. Crematogaster biroi Mayr. $\Varangle-$ Two specimens from Canton.

12. Pheidologeton diversus Jerd. $4 \quad \Varangle-$ Many workers and a single soldier from Canton. One lot of workers attending scaleinsects.

\footnotetext{
1 Contributions from the Entomological Laboratory of the Bussey Institution, Harvard University. No. 194.

2 Bull. Mus. Comp. Zool. 64, 1921, pp. 529-547.
} 


\section{DOLICHODERIN A.}

13. Dolichoderus (Hypoclinea) taprobano Sm. var. gracilipes Mayr. $\Varangle$ 우 $\hat{o}$-Numerous specimens from Canton.

14. Dolichoderus (Hypoclinea) affinis Emery var. nigricans Emery. ఫ-Numerous specimens from Tei-loi and Loh-Kong, Canton.

15. Dolichoderus (Hypoclinea) sinensis sp. nov. (Fig. 1).

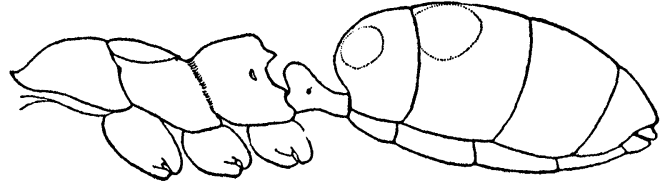

Fig.1 Dolichoderus (Hypoclin a) sinonsis, sp. nov., worker.

Worker. Length $3.4 \mathrm{~mm}$.

Closely related to the Palearctic $D$. quadripunctatus L. but differing in the following particulars: Joints $3-\%$ of funiculi shorter, not longer than broad; mesonotum slightly longer, more nearly parallel-sided; base of epinotum much more elevated and convex and broader in proportion to its length; its posterior corners depressed and developed as small, rather acute teeth, not as tubercles. Petiolar node distinctly lower and more evenly rounded above in profile, the cylindrical portion behind the node longer.

Surface of head, thorax and petiole much more opaque; the foveolæ on the head and thorax more regular and more distinct. Mandibles, clypeus and pleuræ slightly shining, or lustrous, finely shagreened. Gaster very smooth and shining.

Pilosity and pubescence quite as feebly developed as in quadripunctatus.

Head, thorax, petiole and legs deep red, the tibiæ slightly darker; tarsi, mandibles and antennæ slightly paler, the tips of the scapes and funiculi infuscated. Gaster black; first and second segments as in quadripunctatus, each anteriorly with a pair of ivory yellow but somewhat larger spots.

Described from a single specimen from Canton.

16. Technomyrmex albipes Sm. $\Varangle-N u m e r o u s ~ s p e c i m e n s$ from Canton; attending mealy bugs.

1\%. Iridomyrmex anceps Roger $\Varangle-N i n e$ specimens from Canton.

18. Tapinoma indicum Forel $\Varangle-S i x$ specimens from Leng-oo. 


\section{FORMICINA.}

19. Plagiolepis longipes Jerd. ఫ๐-Several specimens from Canton.

20. Plagiolepis rothneyi Forel $\Varangle-$ Numerous specimens from Canton.

21. Paratrechina longicornis Fabr. $\Varangle-N u m e r o u s ~ s p e c i m e n s$ from Canton.

22. Paratrechina (Nylanderia) yerburyi Forel $\Varangle-N u m e r o u s$ specimens from Canton.

23. Gesomyrmex howardi sp. nov. (Fig. 2).

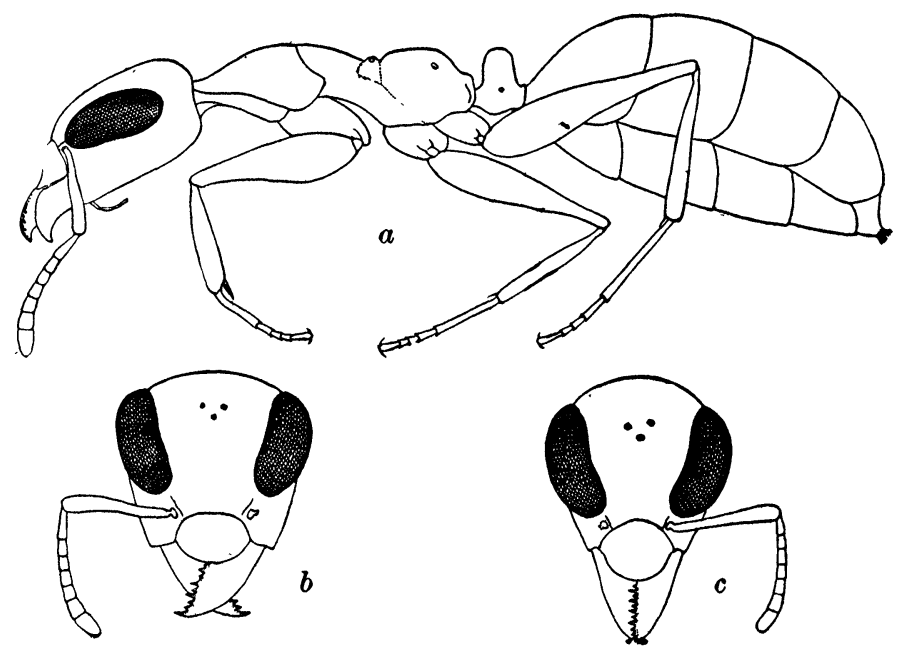

Fig. 2. Gesmoyrmex howardi sp. nov. a, worker major; b, head of same, c, head of worker minor.

Worker major. Length $3 \mathrm{~mm}$.

Head, without the mandibles, a little longer than broad, broader behind than in front, with straight, anteriorly angular cheeks, convex and broadly rounded posterior border and corners, broadly and arcuately excised occipital border and rather flat dorsal and gular surfaces. Eyes very large, prominent, elliptical, fully $21 / 2$ times as long as broad, situated at the middle of the sides of the head. Ocelli minute but distinct. Mandibles rather flat, their external borders straight at the base, convex towards the tips, their apical borders straight with acute, crowded teeth, alternately long and short. Clypeus broader than long, convex but not carinate in the middle, flattened and depressed anteriorly where it projects as a broad, arcuate lobe over the bases of the mandibles. Frontal 
carinæ very short, twice as far apart as their distance from the lateral borders of the head, running back towards the anterior orbits. Frontal area and groove obsolete. Antennæ short, 8-jointed, scapes somewhat thickened apically, not reaching to the posterior orbits; funiculi gradually thickened to their tips, all their joints longer than broad. Thorax long and slender; broadest through the pronotum, much narrowed at the mesonotum; pronotum seen frow above elliptical, a little longer than broad, its dorsal outline evenly rounded, continued back into that of the sloping mesonotum to the constriction, which is sellate and bears on each side a swelling with one of the metanotal spiracles. Base of epinotum rising somewhat above the constriction, slightly but distinctly convex, longer than the feebly concave, sloping declivity. From above the epinotum is a little longer than broad and slightly narrower than the pronotum, the mesonotum less than half as broad as the latter. Petiolar node nearly as high as the epinotum, transverse, erect, as thick above as below, its anterior and dorsal surface rounded, its posterior surface more flattened; seen from behind it is broader above than below, with broadly rounded superior corners. Gaster moderately large, elliptical, its first segment not longer than the second. Legs moderately long, femora all distinctly incrassated at the base, tibiæ subcylindrical, their bases slightly constricted. Tarsal claws slender and rather straight.

Shining; finely but sharply shagreened; thorax and petiole, except the pronotum, subopaque, finely and densely punctate. Mandibles, clypeus and front of head with fine, dense, superficial, longitudinal striæ.

Hairs and pubescence whitish; the former absent except on the clypeus, palpi and tip of the gaster; the pubescence extremely short and dilute, distinct only on the antennal funculi.

Dull honey yellow; legs scarcely paler; mandibles, clypeus and antennæ more whitish; eyes black; mandibular teeth reddish brown.

Worker minor. Length 2. $3 \mathrm{~mm}$.

Differing from the major in its smaller size, narrower head, proportionally larger, more prominent and slightly more reniform eyes, even more minute ocelli, shorter, less angular and anteriorly more convergent cheeks; longer and more anteriorly produced clypeus and more slender mandibles. 
Described from two specimens from Canton, both from the same vial in which they were mingled with several other ants.

This is the fourth species of Gesomyrmex to come to light. The genus was established by Mayr in $1868^{3}$ for a species, hoernesi, from the Baltic Amber. Emery, in 1891, referred a peculiar form, corniger, from the Sicilian Amber to the same genus, ${ }^{4}$ but I have recently made it the type of a distinct though allied genus, Sicelomyrmex. ${ }^{5}$ In the same paper I described a second species of Gesomyrmex, annectens, from the Baltic Amber. In 1892 Ernest Andre ${ }^{6}$ described and figured an extant species, capperi from the Kapouas Basin of Borneo. This insect has not been seen since. It is therefore of considerable interest to find on the Asiatic continent a second living Gesomyrmex. It is evident that the Bornean and Chinese species are very rare and probably vanishing relicts of a group of Formicinæ with huge eyes and 8-jointed antennæ, which was represented by numerous species during the Oligocene and Miocene Tertiary. To this group we must also assign the allied genera Sicelomyrmex and Dimorphomyrmex. The latter is known from two species from the Baltic Amber, theryi Emery and mayri Wheeler, and three extant species, andrei Emery and janeti Ern. André from Borneo, and luzonensis Wheeler from the Philippines.

Judging from André's figures and description, Gesomyrmex howardi differs from capperi in its smaller size, less reniform eyes, broader pronotum, more cylindrical mesonotum, more convex epinotum, thicker petiole and more uniform honey-yellow color. André's specimens measured 3.5 to $4 \mathrm{~mm}$. and seem to have been minor workers. Since the major worker measures in all probability not far from $4.5 \mathrm{~mm}$. capperi must be considerably larger than the Chinese species. The amber specimens which I described as annectens may, perhaps, be major workers of hoernesi, but the measurements seem not to favor this supposition, since annectens varies from 4 to $6 \mathrm{~mm}$., hoernesi from 2.5 to $6 \mathrm{~mm}$. The great similarity of all four described species of Gesomyrmex leads me

\footnotetext{
${ }^{3}$ Die Ameisen des baltischen Bernsteins. Beitr. Naturk. Preussens. Physik. Cikon. Ges. Königsberg 1, 1868, pp. 1-102, 5 pls.

${ }^{4}$ Le Formiche dell'Ambra Siciliana nel Museo Mineralogica dell'Universita di Bologna. Mem. R. Accad. Sc. Ist. Bologna (5) 1, 1891, pp. 141-165, 3 pl.

S The Ants of the Baltic Amber. Schrift. physik. ökonom. Ges. Königsberg 55, 1914, pp. 1-142, 66 figs.

${ }^{6}$ Voyage de M. Chaper a Borneo. Catalogue des Fourmis et Description des Espèces Nouvelles. Mém. Soc. Zool. France 5, 1892, pp. 46-55, 5 figs.
} 
to suspect that the amber specimens, which I examined, may represent more than two very closely related forms. The worker major of G. howardi shows that the genera Gesomyrmex and $D i$ morphomyrmex are more closely related than was supposed. Nevertheless, the gizzard of $D$. andei figured by Emery ${ }^{7}$ is quite different from the gizzard of $G$. capperi figured by André. In the former insect the organ is short and broad with short, terminally reflected calyx-lobes, in the latter long and slender and more as in Camponotus and Oecophylla.

The thickened bases of the femora of $G$. howardi indicate that this ant can jump like the large-eyed Gigantiops destructor Fabr. of the Neotropical Region, and the rather feeble tarsal claws would seem to indicate that it is not arboreal but nests in the ground.

24. Camponotus (Myrmoturba) nicobarensis Mayr $\Varangle$ $q$-Many specimens from Honan Island, Canton.

25. Camponotus (Myrmoturba) mitis $\mathrm{Sm}$. $\Varangle-$ Many specimens from Canton.

26. Camponotus (Myrmoturba) barbatus Roger var albosparsus Forel $\Varangle-$ Eight specimens from Canton.

27. Camponotus (Myrmosericus) rufoglaucus Jerd. subsp. paria Emery $\Varangle-$ Numerous specimens from Tei-loi, Canton.

28. Polyrhachis (Myrma) mayri Roger $\Varangle-T h r e e$ specimens from Canton.

29. Polyrhacis (Myrmhopla) dives Sm. $\nsucceq$ ô-Numerous specimens from Canton.

30. Polyrhachis (Cyrtomyrma) rastellata Sm. subsp. laevior Roger var. debilis Emery $\Varangle-$ Three specimens from Canton.

${ }^{7}$ Descriptions de deux fourmis nouvelles. Ann. Soc. Ent. France 63, 1894, pp. $72-74,2$ figs. 

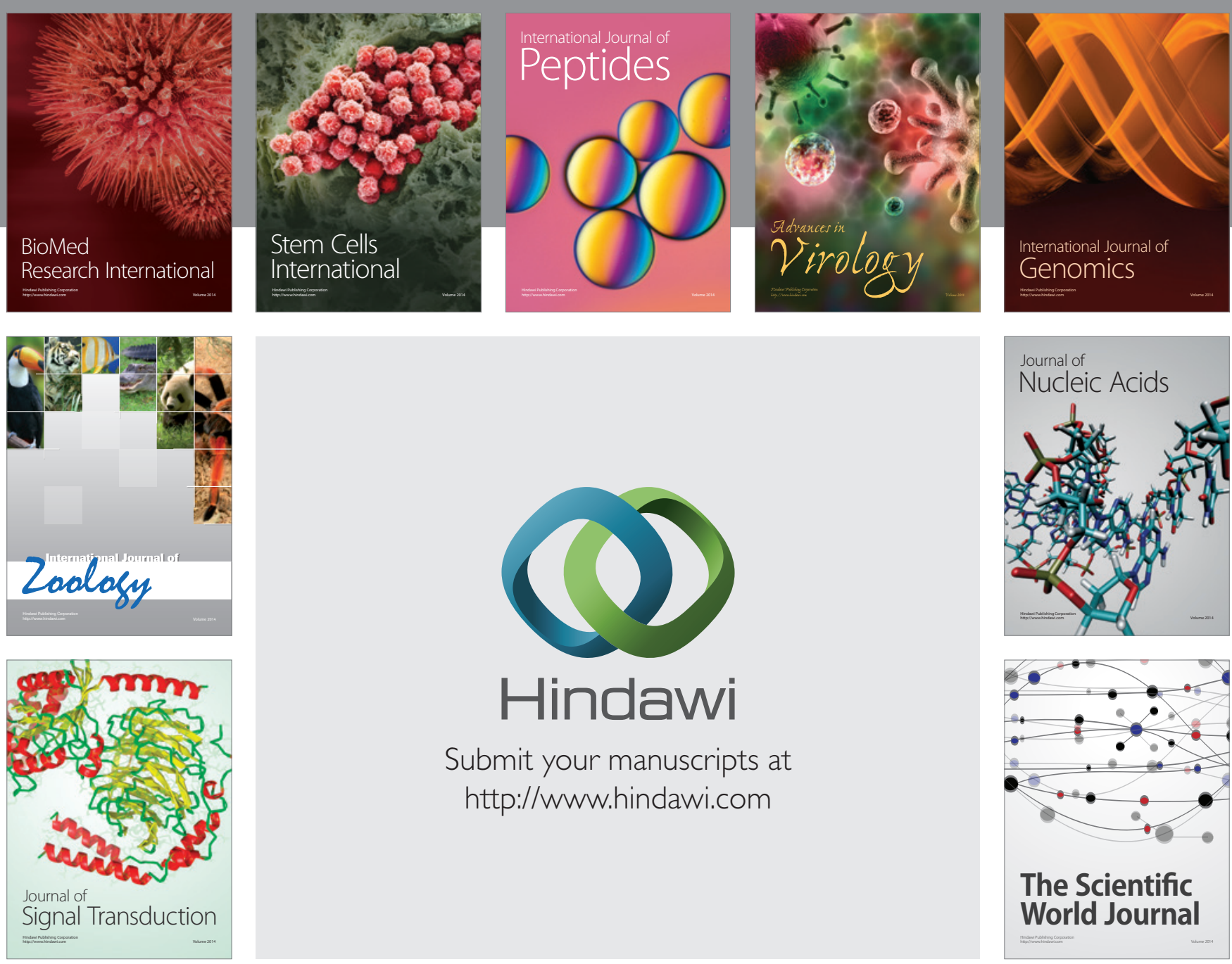

Submit your manuscripts at

http://www.hindawi.com
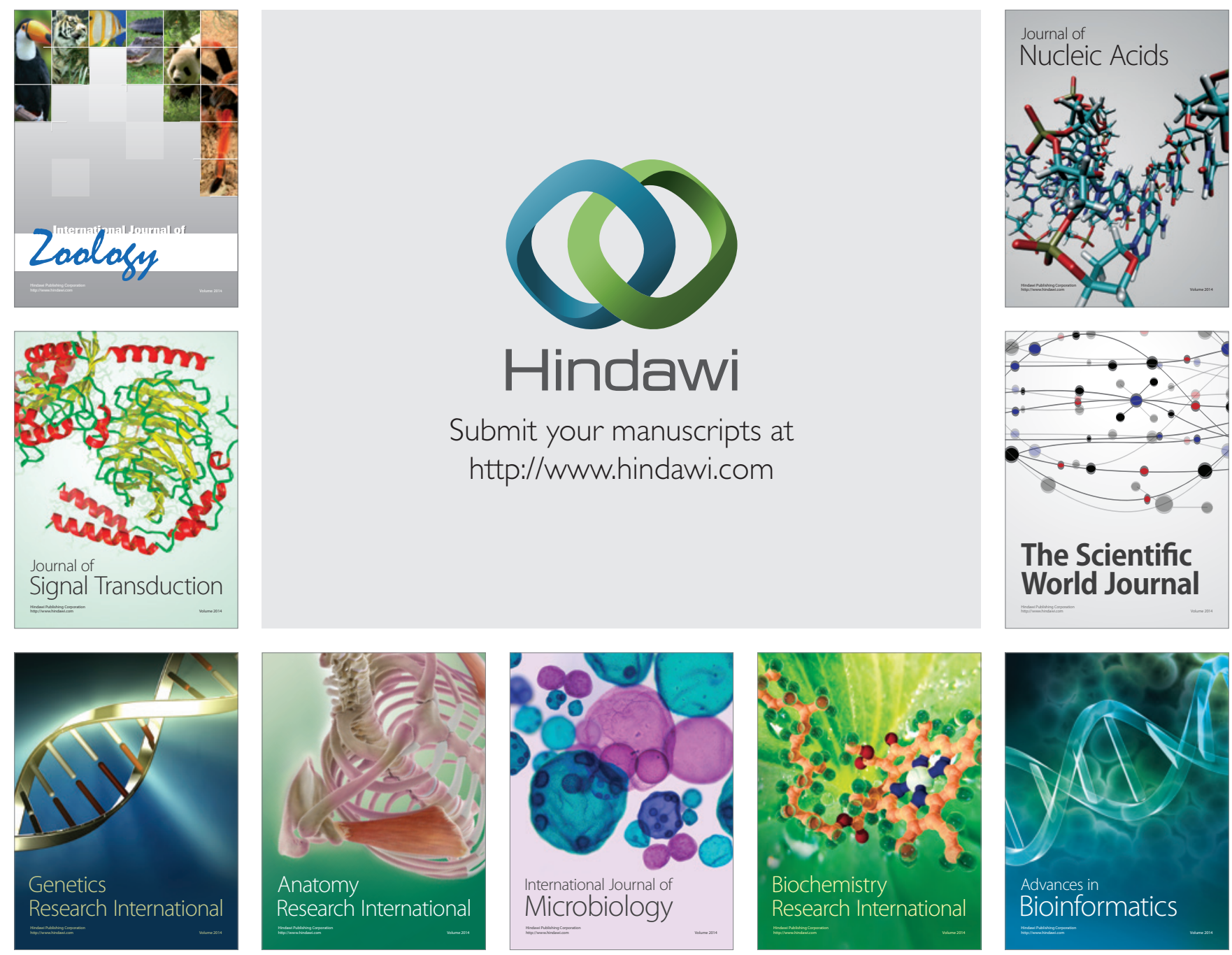

The Scientific World Journal
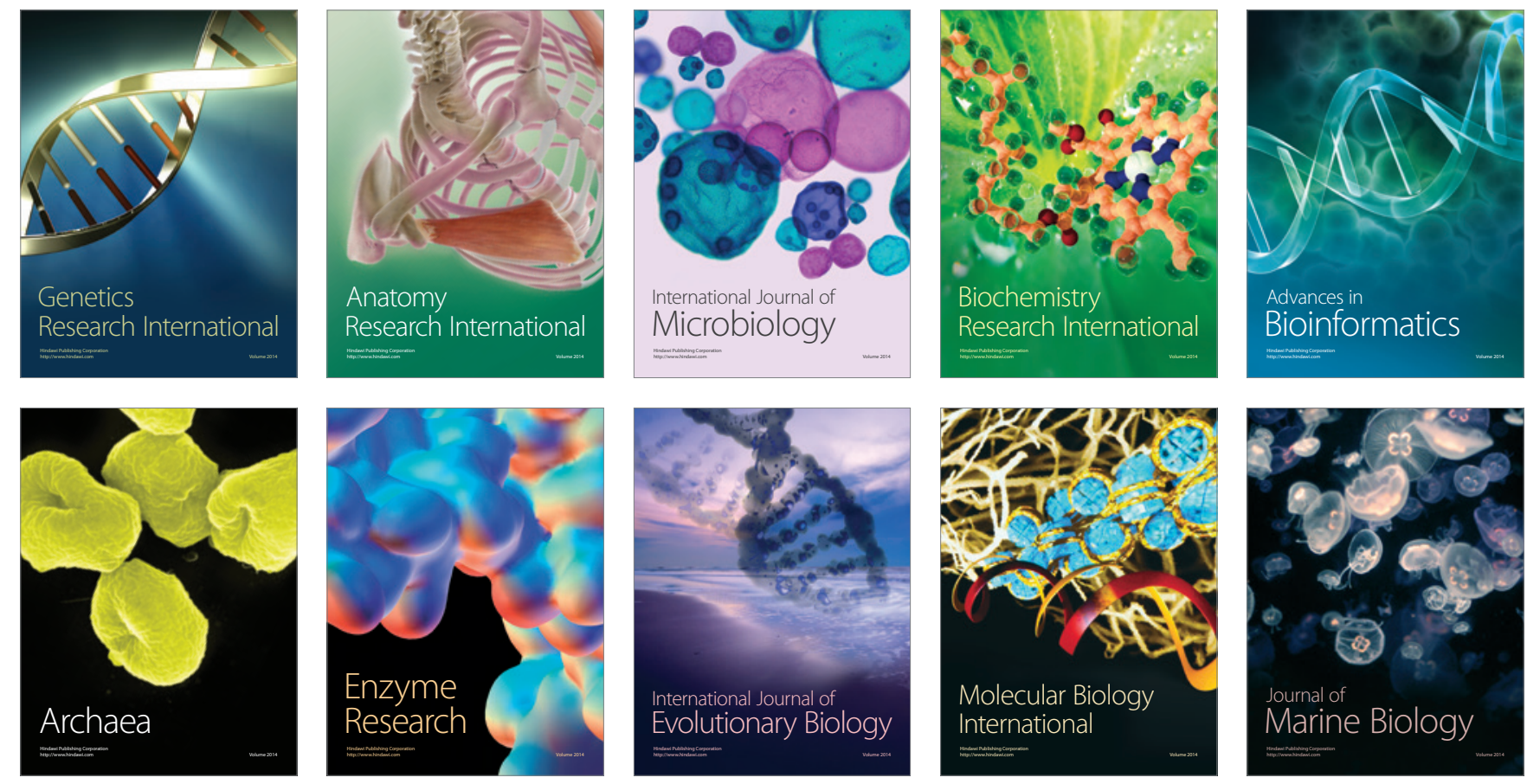